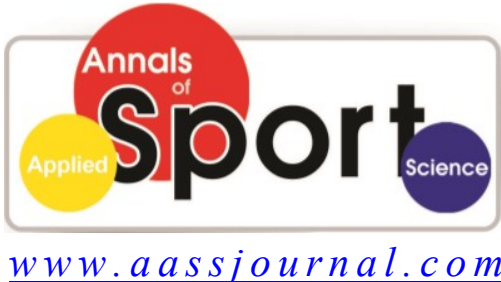

ISS N (Online): $2322-4479$

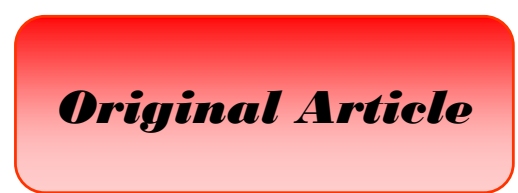

Received: $10 / 05 / 2014$

Accepted: 12/11/2014

\title{
Effects of Endurance and Circuit Resistance Trainings on Lipid Profile, Heart Rate, and Hematological Parameters in Obese Male Students
}

\author{
${ }^{1}$ Mehdi Mogharnasi*, ${ }^{2}$ Rasul Eslami, ${ }^{3}$ Behzad Behnam
}

1. Department of Physical Education, University of Sistan \& Baluchestan, Zahedan, Iran.

2. Faculty of Physical Education and Sport Science, Allameh Tabataba'i University, Tehran, Iran.

3. Department of Physical Education, Kerman Science and Research branch, Islamic Azad University, Kerman, Iran.

\begin{abstract}
Studies have shown that different exercise ways are of the most important factors that affect cardiovascular risk factors and hematological parameters. This present paper aims to study the effects of two methods of endurance and resistance training on lipid profiles, heart rate, and hematological parameters in obese male students. 36 obese students were purposefully selected and randomly divided into three groups of 12 including endurance exercise, resistance exercise, and control. Exercise program was performed 3 times a week for 8 weeks, with a specific duration and intensity in both endurance and resistance exercise groups. Blood sampling was done after 14 fasting before the trial and 48 hours after the last training session. Results showed that both resistance and endurance exercises significantly increased HDL-C, Hct, and $\mathrm{Hb}$ and significantly decreased $\mathrm{TC}, \mathrm{TG}$, and resting heart rate $(\mathrm{P}<0.05)$. Also, Resistance exercise significantly increased the PLT and decreased LDL-C $(\mathrm{P}<0.05)$. However, WBC and RBC showed no significant change in the resistance and endurance exercise groups $(\mathrm{P}>0.05)$. In addition, no significant difference was observed between endurance and resistance exercise $(\mathrm{P}>0.05)$. In general, both endurance and resistance exercises can affect the lipid profile and hematological parameters and also reduce the resting heart rate. Therefore, they can be considered as an appropriate and non-medication approaches to prevent and reduce the incidence of cardiovascular diseases and obesity-related disorders in obese male adolescents.
\end{abstract}

Key Words: Endurance Exercise, Resistance Exercise, HDL-C, LDL-C, TC, TG, PLT, Hct, and Hb.

Corresponding Author:

Mehdi Mogharnasi

E-mail: mogharnasi@ped.usb.ac.ir 


\section{INTRODUCTION}

Diseases threatening human health are of the issues that have occupied the minds of researchers. A group of these diseases are cardiovascular ones that take the lives of about 12000000 people annually, according to the existing reports (1). One of the main risk factors of cardiovascular diseases is obesity, a medical condition in which body fats are unusually increased (2). In fact, obesity is an unusual phenomenon in children and there is no evidence that obesity in childhood also continues until adulthood and affects a long period of one's life. However, recent studies have demonstrated that dramatic changes have occurred in the health status of children and adolescents because of wrong nutrition and lifestyle $(3,4)$. For these reasons and as overweight is an index of inactivity, inactive children and adolescents should participate more in exercise. Almost in all the approaches presented, sport and exercise play an important role in the treatment of obesity (5).

Lipid profile has always been introduced an index of cardiovascular diseases and increased LDL-C (Low Density Lipoprotein) and decreased HDL-C (High Density Lipoprotein) are considered as the main risk factors of cardiovascular diseases. Control of risk factors of lipid profile, obesity, and overweight is one of the most important strategies for improving human health and any disorder in these parameters can lead to the development of cardiovascular diseases (1). Several reports suggest that regular endurance exercises improve the lipid profile, that is to say, reduced total cholesterol, triglyceride, and LDL-C and increased HDL$\mathrm{C}(6,7)$. By contrast, some other studies have reported no change in these parameters following the endurance exercises $(8,9)$. Benz et al. (2003) compared the advantages of endurance and resistance exercises and concluded that endurance exercises lead to improved performance and have useful effects on individuals susceptible to cardiovascular diseases and endurance exercises with the proper intensity and duration are more effective than resistance exercises in increasing the levels of HDL-C (10). In a study conducted by Elliott, Sale, and Cable (2002), lipid profile showed no significant change after 8 weeks of resistance exercises (11). Heart rate is one of the most important indicators of health and physical fitness in many sports. Several studies conducted on the impact of exercise on heart rate (12-16) have shown that regular exercise reduces the resting heart rate. Dashti (2011) reported that 8 weeks of selective endurance exercise decreased the resting heart rate (12). Naimi (2003) showed that endurance exercises have no significant effect on heart rate (17). On the other hand, some other studies have found a relationship between hematological parameters and Body Mass Index (BMI) in obese adolescents $(18,19)$. Hematological parameters, especially red blood cells and hemoglobin are responsible for carrying nutrients and oxygen to active tissues and excretion of waste and carbon dioxide from tissues to lungs. The number of red blood cells (RBC) and amount of hemoglobin $(\mathrm{Hb})$ and hematocrit (Hct) are effective in increasing or decreasing the capacity of oxygen transport to tissues and excretion of carbon dioxide (20). Reports suggest that exercise and sport can cause significant changes in the hematological parameters. Fujitsuka et al. (2005) observed an increase in hemoglobin and red blood cells and no significant change in platelets (PLT) in a 12-week trial (21). Mousavizadeh, Ebrahimi, and Nikbakht (2009) found that 8 weeks of endurance exercise caused significant reduction in $\mathrm{Hct}, \mathrm{Hb}$, and $\mathrm{RBC}$ (9). Tayebi et al. (2010) reported an increase in white blood cells (WBC) as a result of resistance exercise (22). Another study reported no change in WBC and an increase in PLT following 4 weeks of exercise (23). 
According to previous studies, firstly, inconsistency between the findings is evident and secondly, most previous studies have examined the effects of endurance exercises. Hence, as there was no available study about the effect of different ways of exercises on lipid profile, heart rate, and hematological parameters in obese male students, the present study was carried out in order to determine the effect of 8 weeks of endurance and resistance exercises on these indices in obese male students.

\section{MATERIALS AND METHODS}

Participants. Statistical population included all male students of guidance schools aged 12-16 in Iranshahr, Sistan \& Baluchestan Province, Iran in the academic year 2012-2013, 50 of whom with a BMI of more than $30 \mathrm{~kg} / \mathrm{m}^{2}$ were selected as the sample. Firstly, height and weight of subjects were measured and their physical condition was examined by a physician. Then, parents were asked to declare their consent with the participation of their children in the trial. Finally, 36 of subjects were selected and randomly divided into three groups of endurance exercise, resistance exercise, and control.

Exercise Protocol. Resistance training program with weights included circuit exercise (8 stations) with one minute rest between stages. The objective of this exercise was the use of different muscles at different stations. In addition, these exercises were aimed to strengthen the muscles and improve cardiovascular endurance (24). This exercise program was performed 3 times a week for 8 consecutive weeks. In each session, about 15 minutes warm-up through stretching motions in the body's major muscles and 45-50 minutes resistance exercise were done. Procedure of training program was as follows: Squat, biceps curl with barbell, bench press, knee extension, seated row, standing calf raise with dumbbells, military press, and knee curl.
To determine the amount of weight used in training, $60 \%-80 \%$ of one maximum repetition was considered for all actions. For this purpose, the maximum weight that each subject would once lift (a maximum repetition) was determined by Brzycki's equation (25):

$1 \mathrm{RM}=$ displaced weight $(\mathrm{kg}): 1.0278$ - (number of repetition to exhaustion $\times \mathbf{0 . 0 2 7 8}$ )

Training was based on increasing overload principle. Therefore, the subjects were asked to add to their repetitions in each session and increase the weight after reaching the limit of 10 reps (24).

Endurance training program included 15 minutes warm-up with stretching motions, walking, running, and then continuous running at a constant rate for 10 minutes with $65-75 \%$ of maximum heart rate (220-age). In order to observe the principle of overload, training was planned in a way that 30 seconds was added to the running time in each session, as this time reached 20 minutes in the last sessions. At the end of each session, cooling was performed through slow running and stretching motions for 10 minutes (24).

Exercise intensity was calculated according to Karvonen formula as follows:

Exercise hear rate $=[(\mathbf{A}-\mathrm{B}) \times$ desired intensity $]+B$ Where, $A$ represents maximum heart rate (220-age) and $B$ denotes resting heart rate (average of three measurements in the morning).

Blood Sampling and Assessment. In order to study biochemical parameters, blood sampling was done 24 hours before the exercise and 48 hours after the last session in all three studied groups. For the first time of blood sampling, the subjects were asked to avoid any strenuous activity from two days before the trial. Ten $\mathrm{ml}$ of blood was taken from the right brachial artery after 14 hours of fasting. The second stage of blood sampling was done 48 hours after the last training session with the same conditions. 
The resulting serums were kept in a freezer at a temperature of $-80^{\circ} \mathrm{C}$. Plasma triglyceride was measured by enzymatic colorimetric method using a kit made by Pars Azmoon Company (Sensitivity: $1 \mathrm{mg} / \mathrm{dl}$, Intra-assay CV\%: 1.6). Total cholesterol was also measured by enzymatic colorimetric method using a kit made by Pars Azmoon Company (Sensitivity: $3 \mathrm{mg} / \mathrm{dl}$, Intra-assay CV\%: 1.4). To measure HDL-C, enzymatic photometric method and a kit made by Pars Azmoon Company (Sensitivity: $1 \mathrm{mg} / \mathrm{dl}$, Intra-assay CV\%: 1.5) were used. Finally, LDL-C was determined by the equation proposed by Friedewald, Levy, and Fredrickson (1972) (26) as follows:

\section{LDL $=$ TC - HDL - TG/0.5}

The resting hear rate was measured by a stethoscope (Hi-tec, made in Canada) in the morning after asking the subjects to take a seat and stay inactive for 5 minutes. This was done three times for each subject and the mean value was recorded as the resting heart rate. To measure $\mathrm{CBC}, 5 \mathrm{ml}$ of venous blood was taken and poured in plastic vials containing $20 \mathrm{ml}$ of an anti-thrombotic substance and quickly transferred to the laboratory in 30 minutes. Blood parameters were measured by Sysmex K800 device (made in Japan) with an accuracy of $10^{7}$ cells per $\mathrm{ml}$.

Statistical Analysis. Descriptive statistic was used to calculate mean and standard deviation. Distribution normality of variables was tested by Kolmogorov-Smirnov test. Also, ANOVA and dependent t-test were used for studying the difference between the groups and comparison of intragroup pretest and posttest, respectively. All statistical analyses were done in SPSS 17 software at a significance level of $\alpha<0.05$.

\section{RESULTS}

Table 1 presents the general characteristics of subjects in three studied groups. Based on the results, there is no significant difference between subjects of three groups in terms of age, weight, and height. Mean weight and body mass index increased in the control group but showed a significant decrease in the endurance and resistance exercise groups.

The results showed that 8 weeks of endurance and resistance trainings caused a significant increase in HDL-C and a significant decrease in $\mathrm{TC}, \mathrm{TG}$, and resting hear rate $(\mathrm{P}<0.05)$. In addition, resistance exercise led to significant decrease of LDL$\mathrm{C} \quad(\mathrm{P}<0.05) \quad$ (table 2). Also, the results showed that 8 weeks of endurance and resistance trainings caused a significant increase in $\mathrm{Hct}, \mathrm{Hb}(\mathrm{P}<0.05)$. In addition, resistance exercise led to significant increase of PLT $(\mathrm{P}<0.05)$. However, none of endurance and resistance exercises had no significant effect on the amounts of RBC and WBC $(\mathrm{P}>0.05)$ (table 3$)$.

\section{DISCUSSION}

The results of the present study showed that 8 weeks of endurance and resistance exercises caused a significant increase in Hct, $\mathrm{Hb}$, and HDL-C and a significant decrease in $\mathrm{TC}, \mathrm{TG}$, and resting hear rate. However, no significant difference was observed between the two training methods. This result is consistent with the findings of previous reports indicating that regular exercise is followed by reduced lipid profile $(6,7,27-30)$ and resting heart rate (12-16) and increased hematological parameters $(31,32)$. By contrast this is inconsistent with the findings of some other studied (11, 33-35). Habibzadeh and Rahmaninia (2011) studied the effect of two months of walking exercise on lipid profile and body mass index in obese girls and their results indicated that body mass index and risk factors of lipid profile decreased significantly but HDL-C showed a significant increase. They suggested that a regular physical activity like walking can change the metabolism of lipoproteins and reduce the risk factors of cardiovascular 
diseases (30). Balas-Nakash et al. (2010) studied the effect of 12 weeks of endurance exercise with two methods of 20-minute and 40-minute two days a week on risk factors of cardiovascular diseases in adolescents and showed that the first method only affects blood pressure, while the second one causes significant decrease in body mass index, blood pressure, and lipid profile. The came to the conclusion that longer aerobic exercises lead to improved health status of people and reduction of some of the risk factors of cardiovascular diseases (28). Atashk et al.
(2012) studied the effect of 10 weeks of longterm resistance exercise on lipid profile in obese men and showed that resistance exercise causes significant reduction in TC of obese men and resistance exercise can be an effective treatment for making favorable changes in lipid profile in obese men (27). It has been shown that the body's endocrine system, during exercise, can use fatty acids as fuel to increase lipolysis through increasing the level of epinephrine, norepinephrine, cortisol, and growth hormone.

Table 1. General characteristics of subjects (Mean \pm SD)

\begin{tabular}{ccccccc}
\hline \multirow{2}{*}{ Group } & Height & Age & \multicolumn{2}{c}{ Weight $(\mathbf{k g})$} & \multicolumn{2}{c}{ BMI (kg/m $\mathbf{2})$} \\
\cline { 4 - 7 } & $\mathbf{( c m )}$ & $\mathbf{( y e a r s )}$ & Pretest & Posttest & Pretest & Posttest \\
\hline Control & $146 \pm 3.85$ & $14.6 \pm 0.31$ & $65.67 \pm 12.51$ & $67.70 \pm 0.31$ & $30.41 \pm 1.31$ & $31.60 \pm 1.26$ \\
Endurance exercise & $143 \pm 3.46$ & $14.32 \pm 0.27$ & $63.16 \pm 8.58$ & $60.66 \pm 8.80^{*}$ & $30.75 \pm 1.21$ & $29.50 \pm 1.31^{*}$ \\
Resistance exercise & $152 \pm 0.15$ & $13.71 \pm 0.29$ & $68.50 \pm 6.97$ & $65.30 \pm 6.94^{*}$ & $29.50 \pm 0.79$ & $28.00 \pm 1.00^{*}$ \\
\hline
\end{tabular}

*Significant level at $\mathrm{p}<0.05$.

Table 2. Analysis of covariance for Lipid Profiles and HRrest

\begin{tabular}{|c|c|c|c|c|c|c|c|}
\hline \multirow{2}{*}{ Variable } & \multirow{2}{*}{ Group } & \multirow{2}{*}{ Pretest } & \multirow{2}{*}{ Posttest } & \multicolumn{3}{|c|}{ Intergroup p-value } & \multirow{2}{*}{$\begin{array}{c}\text { Covariance } \\
\text { p-value }\end{array}$} \\
\hline & & & & Control & Endurance & Resistance & \\
\hline \multirow{3}{*}{$\begin{array}{c}\mathrm{TC} \\
(\mathrm{mg} / \mathrm{dL})\end{array}$} & Control & $210.17 \pm 38.43$ & $211.42 \pm 43.11$ & & $<0.001^{* *}$ & $<0.001^{* *}$ & \multirow{3}{*}{$\begin{array}{c}\mathrm{F}=3.13 \\
\mathrm{p}<0.001^{* * *}\end{array}$} \\
\hline & Endurance & $192.68 \pm 12.45$ & $184.23 \pm 15.25$ & & & 0.962 & \\
\hline & Resistance & $183.8 \pm 9.33$ & $176.08 \pm 9.62$ & & & & \\
\hline \multirow{3}{*}{$\begin{array}{c}\mathrm{TG} \\
(\mathrm{mg} / \mathrm{dL})\end{array}$} & Control & $114.20 \pm 11.90$ & $118.60 \pm 10.70$ & & $0.033^{*}$ & $0.041^{*}$ & \multirow{3}{*}{$\begin{array}{c}F=4.68 \\
0.05^{*}\end{array}$} \\
\hline & Endurance & $114.30 \pm 9.58$ & $107.41 \pm 11.13$ & & & 0.877 & \\
\hline & Resistance & $112.69 \pm 7.96$ & $102.77 \pm 7.96$ & & & & \\
\hline \multirow{3}{*}{$\begin{array}{l}\text { LDL-C } \\
(\mathrm{mg} / \mathrm{dL})\end{array}$} & Control & $104.50 \pm 10.60$ & $107.70 \pm 13.40$ & & 0.13 & $0.005^{* *}$ & \multirow{3}{*}{$\begin{array}{c}F=4.68 \\
0.017^{*}\end{array}$} \\
\hline & Endurance & $103.40 \pm 7.50$ & $100.73 \pm 11.66$ & & & 0.131 & \\
\hline & Resistance & $100.82 \pm 6.28$ & $94.99 \pm 5.42$ & & & & \\
\hline \multirow{3}{*}{$\begin{array}{l}\text { HDL-C } \\
(\mathrm{mg} / \mathrm{dL})\end{array}$} & Control & $41.08 \pm 6.89$ & $40.83 \pm 5.00$ & & $<0.001^{* *}$ & $<0.001^{* *}$ & \multirow{3}{*}{$\begin{array}{c}\mathrm{F}=11.184 \\
<0.001^{* *}\end{array}$} \\
\hline & Endurance & $40.50 \pm 2.60$ & $44.00 \pm 3.30$ & & & 0.711 & \\
\hline & Resistance & $43.80 \pm 5.00$ & $42.20 \pm 4.70$ & & & & \\
\hline \multirow{3}{*}{$\begin{array}{l}\text { HRrest } \\
(\mathrm{b} / \mathrm{min})\end{array}$} & Control & $74.60 \pm 4.70$ & $75.60 \pm 4.60$ & & $<0.001^{* * *}$ & $<0.001^{* *}$ & \multirow{3}{*}{$\begin{array}{l}F=50.56 \\
<0.001^{* *}\end{array}$} \\
\hline & Endurance & $76.40 \pm 3.91$ & $69.75 \pm 4.45$ & & & 0.512 & \\
\hline & Resistance & $76.50 \pm 4.70$ & $70.33 \pm 4.51$ & & & & \\
\hline
\end{tabular}

$*$ Significant level at $\mathrm{p}<0.05$. **Significant level at $\mathrm{p}<0.01$. 
Table 3. Analysis of covariance for Hematological Parameters

\begin{tabular}{|c|c|c|c|c|c|c|c|}
\hline \multirow{2}{*}{ Variable } & \multirow{2}{*}{ Group } & \multirow{2}{*}{ Pretest } & \multirow{2}{*}{ Posttest } & \multicolumn{3}{|c|}{ Intergroup p-value } & \multirow{2}{*}{$\begin{array}{c}\text { Covariance } \\
\text { p-value }\end{array}$} \\
\hline & & & & Control & Endurance & Resistance & \\
\hline \multirow{3}{*}{$\begin{array}{c}\mathrm{RBC} \\
\left(10^{6} / \mu \mathrm{L}\right)\end{array}$} & Control & $5.44 \pm 0.60$ & $5.55 \pm 0.86$ & & & & \multirow{3}{*}{$\begin{array}{c}F=1.04 \\
0.365\end{array}$} \\
\hline & Endurance & $4.90 \pm 0.60$ & $4.77 \pm 0.72$ & & & & \\
\hline & Resistance & $4.80 \pm 0.60$ & $4.99 \pm 0.39$ & & & & \\
\hline \multirow{3}{*}{$\begin{array}{c}\text { WBC } \\
\left(10^{3} / \mu \mathrm{L}\right)\end{array}$} & Control & $6.37 \pm 0.94$ & $6.40 \pm 0.75$ & & & & \multirow{3}{*}{$\begin{array}{c}\mathrm{F}=2.561 \\
0.095\end{array}$} \\
\hline & Endurance & $6.07 \pm 0.34$ & $6.94 \pm 0.34$ & & & & \\
\hline & Resistance & $5.98 \pm 0.50$ & $7.04 \pm 0.82$ & & & & \\
\hline \multirow{3}{*}{$\begin{array}{l}\mathrm{Hb} \\
(\mathrm{g} / \mathrm{L})\end{array}$} & Control & $14.35 \pm 1.62$ & $13.85 \pm 1.75$ & \multirow{3}{*}{\multicolumn{2}{|c|}{$0.01^{* *}$}} & $<0.001^{* *}$ & \multirow{3}{*}{$\begin{array}{c}\mathrm{F}=10.609 \\
<0.001\end{array}$} \\
\hline & Endurance & $14.92 \pm 0.67$ & $15.14 \pm 0.64$ & & & 0.516 & \\
\hline & Resistance & $14.53 \pm 0.92$ & $14.91 \pm 0.65$ & & & & \\
\hline \multirow{3}{*}{$\begin{array}{l}\text { Hct } \\
(\%)\end{array}$} & Control & $42.70 \pm 3.60$ & $41.80 \pm 5.14$ & \multirow{3}{*}{\multicolumn{2}{|c|}{$0.029^{*}$}} & $0.021^{*}$ & \multirow{3}{*}{$\begin{array}{c}\mathrm{F}=3.629 \\
0.039^{*}\end{array}$} \\
\hline & Endurance & $46.50 \pm 3.60$ & $47.30 \pm 2.95$ & & & 0.886 & \\
\hline & Resistance & $45.25 \pm 3.98$ & $47.08 \pm 3.70$ & & & & \\
\hline \multirow{3}{*}{$\begin{array}{c}\text { PLT } \\
(1000 / \mu \mathrm{L})\end{array}$} & Control & $228.16 \pm 35.74$ & $228.50 \pm 35.51$ & \multirow{3}{*}{\multicolumn{2}{|c|}{0.459}} & $0.013^{*}$ & \multirow{3}{*}{$\begin{array}{c}\mathrm{F}=3.833 \\
0.033^{*}\end{array}$} \\
\hline & Endurance & $256.50 \pm 46.60$ & $262.00 \pm 51.30$ & & & 0.058 & \\
\hline & Resistance & $237.80 \pm 32.70$ & $260.30 \pm 41.70$ & & & & \\
\hline
\end{tabular}

${ }^{*}$ Significant level at $\mathrm{p}<0.05 .{ }^{* *}$ Significant level at $\mathrm{p}<0.01$.

The present study showed that resistance exercise can significantly reduce LDL-C. It is known that at least two key enzymes in the metabolism of lipoproteins are associated with physical activities; Lipoprotein lipase plays a major role in the conversion of LDL$\mathrm{C}$ to HDL-C and its level and activity increases following exercise. In addition, it seems that increased HDL-C as a result of endurance exercises is due to its increased production by liver enzymes and changes in different enzymes such as increase in lipoprotein lipase and lecithin cholesterol acyl transferase and decrease in hepatic lipase activity. Hepatic lipase enzyme plays a major role in the conversion of LDL-C to HDL-C. The amount of this enzyme is less in active individuals and exercise can decrease it more and maintain HDL-C concentration in larger amounts. These enzymatic changes, which are caused by exercise, improve the lipid profile $(6,7)$.

According to the study findings, 8 weeks of resistance and endurance exercises caused a significant change in heart rate compared with the control group. This is consistent with the results of Ravasi et al. (2003), Naimi (2003), Dashti (2011), and Lee et al. (2010) (12, 15-17). Ravasi et al. (2003) studied the impact of breath control exercises on peak aerobic power (Vo2max), resting heart rate, and erythropoietin in male physical education students. The subjects were under the treatment of interval and hypoxic interval running for 8 weeks. The results showed that 8 weeks of exercise in both groups caused significant decrease in heart rate (16). Dashti (2011) studied the effect of selective exercise on body composition and heart rate in male students aged 11-13 and observed that 8 weeks of exercise was associated with a significant reduction in resting heart rate (12). Lee et al. (2010) studied the effect of exercise on physical characteristics, metabolic condition, and cardiovascular parameters in obese children and the results showed that heart rate significantly decreased after the exercise compared with the control group (15). The results of the present study are inconsistent with the findings of Khashef (2002) who studied the effect of one session of strenuous physical activity and active and 
passive recovery on systolic and diastolic blood pressure and heart rate in young men and showed that resting heart rate significantly increased after exercise in all groups (14). Therefore, given the 8 weeks of exercise in the present study, it seems that the intensity was high enough to cause significant changes in resting heart rate. This can explain the partial effect of intensity and duration of exercise on resting heart rate. Heart rate recovery capacity after exercise depends on the capacity of the cardiovascular system to reverse the autonomic nervous system stimulants and adjustments of pressure receptors that are involved during exercise. The initial decrease in heart rate is due to the efforts of parasympathetic nerves for reactivation, with delayed decrease due to continued activity of parasympathetic nerves and reduced influence of sympathetic nerves (21).

The results showed that 8 weeks of resistance and endurance exercises do not make a significant difference in RBC, which is consistent with the findings of Ravasi et al. (2005) and Karakoc (2005). Ravasi et al. (2005) studied the effect of 8 weeks of hypoxic interval exercise on blood parameters in male physical education students and concluded that interval exercise causes no significant change in RBC (32). Karakoc (2005) studied the impact of a 90minute standard football training session on hematological parameters in young men and showed that standard football training has no significant impact on RBC (36). On the other hand, this result is inconsistent with the findings of Mirsasan and Sari Saraf (2001), Mousavizadeh, Ebrahimi, and Nikbakht (2009), and Arazi, Damirchi, and Mostafaloo (2011) and Arazi et al. (2012). Mirsasan and Sari Saraf (2001)studied the effects of intense aerobic activity on RBC indices of male athletes and found that 7 stages of 3-minute Bruce exercise can cause a significant decrease in RBC (37). Arazi, Damirchi, and Mostafaloo (2011) studied the changes in hematological parameters following the repeated sessions of concurrent endurance and resistance exercises for 90 minutes two times a day (morning and afternoon) in male students of physical education and observed that RBC significantly decreased 3 hours after exercise (33).

The findings of the present study also showed that 8 weeks of resistance and endurance exercises do not make a significant difference in WBC. This is consistent with the findings of Ghanbari-Niaki and Mohammadi (2010) who studied the impact of 4 weeks of separate kickboxing and RAST test on hematological parameters in 30 young male boxers and concluded that 4 weeks of exercise has no effect on WBC (23). However, this result is inconsistent with the findings of Arazi, Damirchi, and Mostafaloo (2011), Arazi et al. (2012) and Satarifard, Gaeini, and Choobineh (2012). Arazi, Damirchi, and Mostafaloo (2011) studied the changes in hematological parameters following the repeated sessions of concurrent endurance and resistance exercises for 90 minutes two times a day (morning and afternoon) in males students of physical education and observed that WBC significantly increased 3 hours after exercise (33). Arazi et al. (2012) also studied the response of hematological parameters to different intensities (low, medium, and high) of a resistance circle exercise in male athlete students and found that resistance circle exercise significantly increased WBC in in the high-intensity group (31). Satarifard, Gaeini, and Choobineh (2012) conducted a clinical trial in which 10 young male endurance athletes performed the same exercise for 1 hour with $60 \%$ of maximum oxygen uptake in three normal, cold, and warm environment. The results revealed that endurance exercise lead to significant increase in WBC in all three environments (38). This difference may be due to the characteristics of subjects and duration, intensity, and type of exercise. 
Study findings also showed that 8 weeks of resistance and endurance exercises caused significant increase in hemoglobin in endurance and resistance groups. This result is consistent with the findings of Ravasi, Gaeini, and Elmieh (2005) and Arazi et al. (2012) (31,32). Arazi et al. (2012) studied the response of hematological parameters to different intensities (low, medium, and high) of a resistance circle exercise in male athlete students and found that resistance circle exercise caused significant increase in $\mathrm{Hb}$ in two medium-intensity and high-intensity groups (31). However, this result is inconsistent with the findings of Mirsasan and Sari Saraf (2001), Mousavizadeh, Ebrahimi, and Nikbakht (2009), Arazi, Damirchi, and Mostafaloo (2011), and Karakoc et al. (2005) (9, 33, 36, 37). Mirsasan and Sari Saraf (2001) observed significant decrease in hemoglobin following 7 stages of 3-minute Bruce exercise (37). Mousavizadeh, Ebrahimi, and Nikbakht (2009) studied the effect of an 8-week selective aerobic exercise course on hematological parameters in female students and observed a significant reduction in $\mathrm{Hb}$ (9). Arazi, Damirchi, and Mostafaloo (2011) studied the changes in hematological parameters following the repeated sessions of concurrent endurance and resistance exercises for 90 minutes two times a day (morning and afternoon) in male students of physical education and observed a significant decrease in $\mathrm{Hb}$ three hours after the exercise (33). Karakoc et al. (2005) studied the impact of a 90-minute standard football training session on hematological parameters in young men and showed that that standard football training causes a significant decrease in hemoglobin (36). Thus, given the 8 weeks of exercise in the present study, it seems that the intensity was high enough to cause significant changes in hemoglobin. In addition, some researchers have reported no change in $\mathrm{Hb}$ after exercise $(32,39)$. In this study, $\mathrm{Hb}$ showed a significant decrease in the control, significant increase in the resistance group, and insignificant increase in the endurance group. This indicates the partial effectiveness of duration and intensity of resistance exercise on $\mathrm{Hb}$.

The results of the present study also showed that 8 weeks of resistance and endurance exercises caused a significant increase in Hct (hematocrit). This is consistent with the findings of Ravasi, Gaeini, and Elmieh (2005) and Arazi et al. (2012) (31, 32). Ravasi, Gaeini, and Elmieh (2005) studied 8 weeks of hypoxic interval exercise on blood parameters in male physical education students and concluded that hypoxic interval exercises can cause an increase in Hct (32). Arazi et al. (2012) the response of hematological parameters to different intensities (low, medium, and high) of a resistance circle exercise in male athlete students and found that resistance circle exercise caused significant increase in Hct in all three intensities (31). However, this result is inconsistent with the findings of Mirsasan and Sari Saraf (2001), Mousavizadeh, Ebrahimi, and Nikbakht (2009), and Arazi, Damirchi, and Mostafaloo (2011) $(9,33,37)$. Mirsasan and Sari Saraf (2001) studied the effects of intense aerobic activity on RBC indices of male athletes and found that 7 stages of 3-minute Bruce exercise can cause a significant decrease in Hct (37). Mousavizadeh, Ebrahimi, and Nikbakht (2009) studied the effect of an 8-week selective aerobic exercise course on hematological parameters in female students and observed a significant reduction in het (9). Therefore, given the 8 weeks of exercise in the present study, it seems that the intensity duration was not high enough to cause significant changes in Hct.

In terms of PLT, 8 weeks of resistance and endurance exercises caused a significant increase only in the resistance group, which is consistent with the findings of Arazi, Damirchi, and Mostafaloo (2011), Karakoc et al. (2005), and Ghanbari-Niaki and 
Mohammadi (2010) (23, 33, 36), but inconsistent with the findings of Fujitsuka et al. (2005) who found no significant change in PLT in men following 12 weeks of heavy physical exercise (21).

Generally, it can be interpreted that regular exercise through hemolysis resulting from mechanical or oxidative damages of red cells, also known as hemolysis induced by exercise, causes loss of old cells in small eddy currents and a transfer towards younger cells occurs in $\mathrm{RBC}$ indices. Although the exact mechanism of WBC changes in sport is unknown, some mechanical factors such as increased cardiac output and changes in capillary endothelial cells are probably involved in this process, because, as we know, less than half the body's mature leukocytes circulate in the vascular system when we are resting. In addition, there is strong evidence that emphasizes on the role of hormones, as the regulators of exerciseinduced changes, in leukocyte count and distribution of its subpopulations. It is clear that hormones such as epinephrine and cortisol affect the distribution of leukocytes between blood circulation system and various parts of the body such as liver, spleen, and bone marrow. Additionally, increased leukocyte count during exercise is controlled by epinephrine. Increase in epinephrine and cortisol, which is influenced by the intensity of activity and exercise capacity of individuals, is observed on the threshold of $60 \%$ of maximal oxygen uptake. Number of platelets increases after exercise which is due to the release of new platelets from the vascular bed of spleen, bone marrow, and other platelet deposits in the body. Secretion of epinephrine causes a strong contraction in the spleen where about one-third of body's platelets is deposited there. This mechanism could explain the reason for the dramatic increase in the number of platelets during exercise. In addition, in the acute phase of platelet activation, increase in the volume of platelets may be because of deformation of megakaryocytes parts in the cytoplasm $(9,21$, 22).

\section{CONCLUSION}

The study findings show that both ways of regular exercise including resistance (60-80\% of 1RM) and endurance (65-75\% of HRmax), with favorable effects on risk factors of lipid profile and hematological parameters and also reducing the resting heart rate, are appropriate and non-medication approaches to prevent and reduce the incidence of cardiovascular diseases and obesity-related disorders in male obese adolescents.

\section{ACKNOWLEDGMENTS}

The present paper has been extracted from the Master's thesis of the third author. We would like to kindly thank all male students of guidance schools in Iranshahr, Sistan \& Baluchestan Province, Iran who sincerely helped us and cooperated in in this research.

\section{REFFRENCES}

1. Hopper CA, Gruber MB, Munoz KD, MacConnie SE, Pfingston YM, Nguyen K. Relationship of blood cholesterol to body composition, physical fitness, and dietary intake measures in third-grade children and their parents. Research quarterly for exercise and sport. 2001;72(2):182-8.

2. Wabitsch M. Overweight and obesity in European children: definition and diagnostic procedures, risk factors and consequences for later health outcome. European journal of pediatrics. 2000;159 Suppl 1:S8-13.

3. Sarlio-Lähteenkorva S. Weight Loss and Quality of Life among Obese People. Social Indicators Research. 2001;54(3):329-54.

4. Wagner N, Meusel D, Kirch W. Nutrition education for children-results and perspectives. J Public Health. 2005;13(2):102-10.

5. Hare SW, Price JH, Flynn MG, King KA. Attitudes and perceptions of fitness professionals regarding obesity. Journal of community health. 2000;25(1):5-21.

6. Crimi E, Ignarro LJ, Cacciatore F, Napoli C. Mechanisms by which exercise training benefits patients with heart failure. Nature reviews Cardiology. 2009;6(4):292-300. 
7. Zabet A, Souri R, Salehian O. The Effect of Aerobic Activity on Cardiovascular Markers (ICAM-1, VCAM-1 and Lipid Profile) in Sendentary Obese Men. Journal of Sport Biosciences. 2010;2(5):19-35 [Article in Farsi].

8. Davis PG, Bartoli WP, Durstine JL. Effects of acute exercise intensity on plasma lipids and apolipoproteins in trained runners. Journal of applied physiology (Bethesda, Md : 1985). 1992;72(3):914-9.

9. Mousavizadeh MS, Ebrahimi K, Nikbakht H. Effect of one period of selective aerobic training on hematological indexes of girls. Sci J Iran Blood Transfus Organ. 2009;6(3):227-31 [Article in Farsi].

10. Banz WJ, Maher MA, Thompson WG, Bassett DR, Moore W, Ashraf M, et al. Effects of resistance versus aerobic training on coronary artery disease risk factors. Experimental biology and medicine (Maywood, NJ). 2003;228(4):434-40.

11. Elliott KJ, Sale C, Cable NT. Effects of resistance training and detraining on muscle strength and blood lipid profiles in postmenopausal women. British journal of sports medicine. 2002;36(5):340-4.

12. Dashti MH. The effect of programmed exercise on body compositions and heart rate of 11-13 years-old male students. Zahedan Journal of Research in Medical Sciences. 2011;13(6):40-3.

13. Ghods Mirheidari S, Takally H. Analyzing and Studying the Effects of Interval Training on Students Heart Rate. HARAKAT. 2004(18):153-60 [Article in Farsi].

14. Kashef M. Effect of high intensity physical activity; active recovery and inactive recovery on systolic and diastolic hypertension and heart rate in young male. Olympic. 2002;10(1-2):29-40 [Article in Farsi].

15. Lee YH, Song YW, Kim HS, Lee SY, Jeong HS, Suh SH, et al. The effects of an exercise program on anthropometric, metabolic, and cardiovascular parameters in obese children. Korean circulation journal. 2010;40(4):179-84.

16. Ravasi AA, Gaeini AA, Javadi E, Elmieh A. Effect of Internal Hypoxic Training on Maximal Aerobic Capacity, Resting Heart Rate and Erythropoietin. HARAKAT. 2003;14:39-52 [Article in Farsi].

17. Naimi SS. Effects of Duration and Severity of Aerobic Training Program on Heart Rate in Inactive Young Females. Pejouhandeh. 2003;7(4):289-94 [Article in Farsi].

18. Kelishadi R, Hashemipour M, Ashtijou P, Mirmoghtadaee P, Poursafa P, Khavarian N, et al. Association of cell blood counts and cardiometabolic risk factors among young obese children. Saudi medical journal. 2010;31(4):40612.

19. Kinik ST, Ozbek N, Yucel M, Haberal A, Cetintas S. Correlations among serum leptin levels, complete blood count parameters and peripheral $\mathrm{CD} 34(+)$ cell count in prepubertal obese children. Annals of hematology. 2005;84(9):605-8.

20. Gaeini AA. The Effect of Maximal Exercise on Hematological Parameters in Athlete \& Non - Athlete Young Student. Olympic. 2001;9(3-4):9-22 [Article in Farsi].

21. Fujitsuka S, Koike Y, Isozaki A, Nomura Y. Effect of 12 weeks of strenuous physical training on hematological changes. Military medicine. 2005;170(7):590-4.

22. Tayebi M, Agha Alinejad H, Kiadaliri K, Ghorbanalizadeh Ghaziani F. Assessment of CBC in physical activity and sport: a brief review. Sci J Iran Blood Transfus Organ. 2011;7(4):249-65 [Article in Farsi].

23. Ghanbari-Niaki A, Mohammadi S. Effect of 4 Weeks of an Aerobic (Rast) Training on Hematological Changes in Male Kick-Boxers

Journal of Applied Exercise Physiology (Journal of Sports Science). 2010;5(10):75-87 [Article in Farsi].

24. Tahmasb M. Effect of short-term detraining period after four weeks endurance and resistance training on leptin, $\mathrm{CRP}$ and Glucose tolerance in untrained young women. Tehran, Iran: Science and Reserch branch-Islamic Azad University; 2012 [Thesis in Farsi].

25. Brzycki M. A Practical Approach to Strength Training. 3rd ed: Masters Press; 1995. 249 p.

26. Friedewald WT, Levy RI, Fredrickson DS. Estimation of the concentration of low-density lipoprotein cholesterol in plasma, without use of the preparative ultracentrifuge. Clinical chemistry. 1972;18(6):499-502.

27. Atashak S, Azarbayjani MA, Piri M, Jafari A. Effects of Combination of Long - Term Ginger Consumption and Resistance Training on Lipid Peroxidation and Insulin Resistance in Obese Men. Journal of Medicinal Plants. 2012;11(42):179-88 [Article in Farsi].

28. Balas-Nakash M, Benitez-Arciniega A, Perichart-Perera O, Valdes-Ramos R, Vadillo-Ortega F. The effect of exercise on cardiovascular risk markers in Mexican school-aged children: comparison between two structured group routines. Salud publica de Mexico. 2010;52(5):398-405.

29. Bouchard C, Shephard R, Stephens T, Sutton J, McPherson B, editors. Exercise, fitness, and health: the consensus statement. International Conference on Exercise, fitness and health; 1988 May 29-June 3, 1988; Toronto, Canada: Human Kinetics Publishers. 
30. Habibzadeh N, Rahmaninia F. A Study of Two Months Walking Exercise on Serum Lipoprotein and Body Mass Index in Obese Girls. Medical Journal of Mashhad University of Medical Sciences. 2011;54(2):100-4 [Article in Farsi].

31. Arazi H, Salehi A, Hosseini Y, Jahanmahin M. The response of hematological factors to a circuit resistance training program with various intensities in athlete male students. Sci J Iran Blood Transfus Organ. 2012;9(1):54-62 [Article in Farsi].

32. Ravasi AA, Gaeini AA, Elmieh A. Effect of Internal Hypoxic Training on Hemogolobin Hematocrite, Reticolucite and Red Blood Cells in Physical Education Students. HARAKAT. 2005(22):121-35 [Article in Farsi].

33. Arazi H, Damirchi A, Mostafaloo A. Variations of hematological parameters following repeated bouts of concurrent enduranceresistance exercise. Journal of Jahrom University of Medical Sciences. 2011;9(2):48-54 [Article in Farsi].

34. Ohkuwa $\mathrm{T}$, Itoh $\mathrm{H}$. High density lipoprotein cholesterol following anaerobic swimming in trained swimmers. The Journal of sports medicine and physical fitness. 1993;33(2):200-2.

35. Suter E, Marti B, Tschopp A, Wanner HU, Wenk C, Gutzwiller F. Effects of self-monitored jogging on physical fitness, blood pressure and serum lipids: a controlled study in sedentary middle-aged men. International journal of sports medicine. 1990;11(6):425-32.

36. Karakoc Y, Duzova H, Polat A, Emre MH, Arabaci I. Effects of training period on haemorheological variables in regularly trained footballers. British journal of sports medicine. 2005;39(2):e4.

37. Mirsasan R, Sari Saraf V. Survey on the Effect of Intensive Aerobic Activity on RBC Indexes in Young Male Athletes. Harakat. 2001(9):89-99 [Article in Farsi].

38. Satarifard S, Gaeini AA, Choobineh S. The Effect of Exercise on the Total Number of Blood Leukocytes and Platelets of the Athletes in Cold, Warm and Normal Temperature Conditions. Armaghan Danesh. 2012;16(5):43343 [Article In Farsi].

39. Bhatti R, Shaikh DM. The effect of exercise on blood parameters. Pak J Physiol. 2007;3(2). 
تازههاى علوم كاربردى ورزش

دوره دوم، شماره جهارم

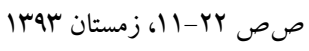

مقاله اصيل

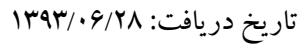

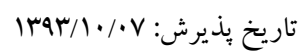

\section{اثر تمرينات استقامتى و مقاومتى دايرهاى بر نيمرخ ليبيدى، ضربان قلب و عوامل هماتولوزيك دانث آموزان يسر جاق} 'مهدى مقرنسى *، 'رسول اسلامى، "بهززاد بهنام

ا. دانشيار فيزيولوزى ورزشى، گروه تربيت بدنى و علوم ورزشى، دانشخاه سيستان و بلوجستان، زاهدان، ايران.

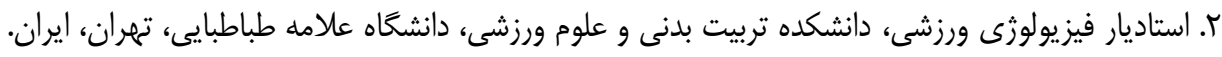

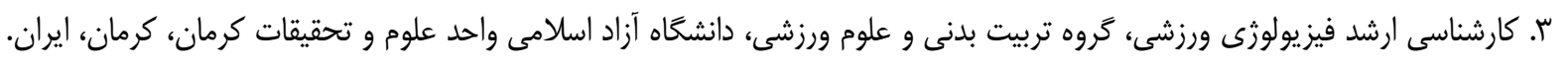

جكيده

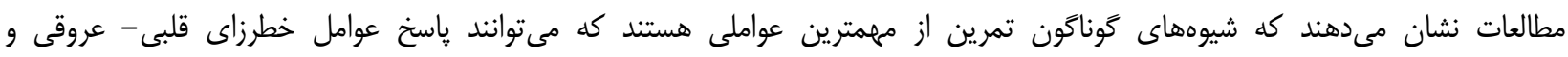

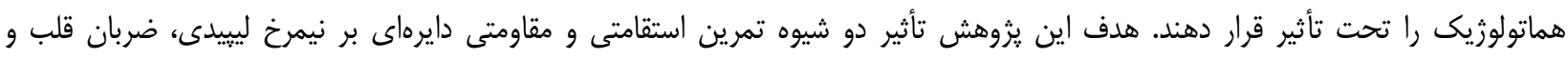

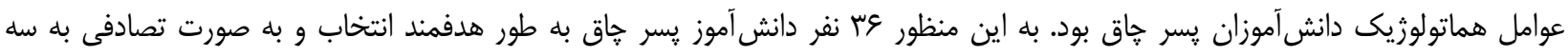

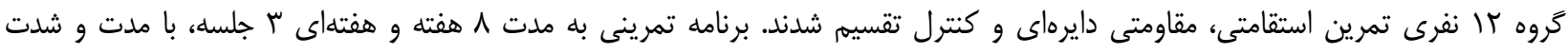

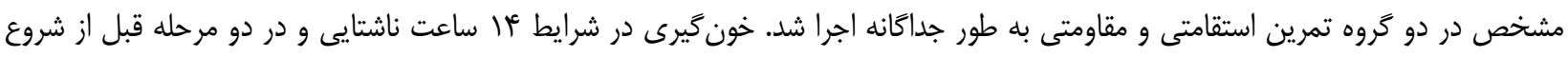

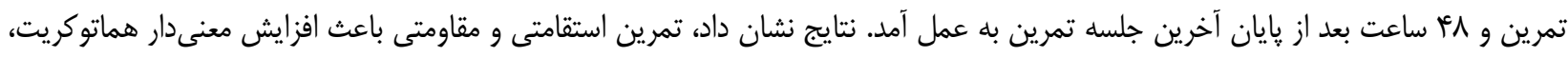

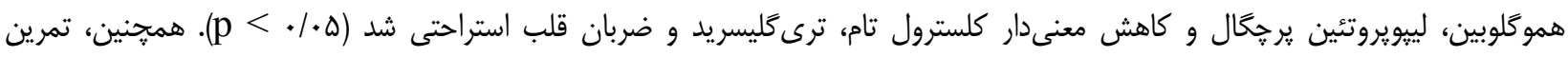

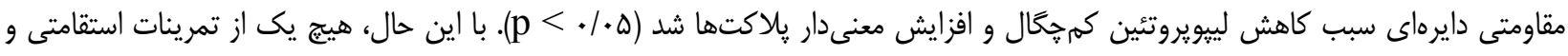

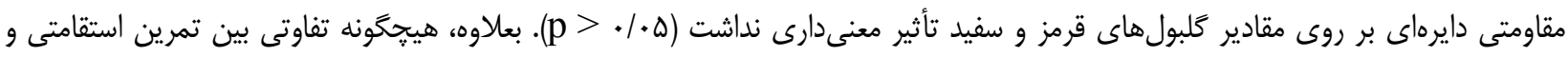

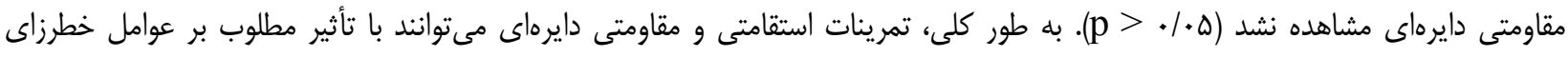

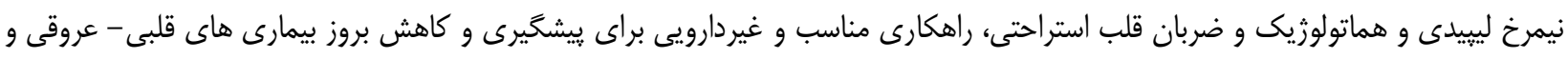

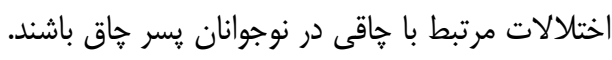

وازَّان كليدى: تمرين استقامتى، تمرين مقاومتى، هماتوكريت، هموكلوبين، لييويروتئين يرجاّال، كلسترول تام، ترى كليسريد، ضربان قلب استراحتى.

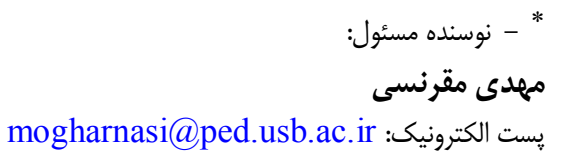

